\title{
FIRST RECORD OF CHORIOACTIS GEASTER FROM OKLAHOMA
}

\author{
Clark L. Ovrebo \\ Department of Biology \\ Sheila Brandon \\ University of Central Oklahoma \\ Fort Towson, OK 74735 \\ Edmond, OK 73034 \\ covrebo@uco.edu
}

Keywords: Ascomycota, Pezizales, cup fungi, biogeography

\begin{abstract}
Chorioactis geaster (Peck) Kupfer, the devil's cigar fungus, is reported from Oklahoma for the first time. A collection was made in Choctaw County in southeast Oklahoma in January 2017. Chorioactis geaster is a fleshy fungus that belongs to the Ascomycota and is an example of what are commonly referred to as cup fungi. The young ascomata are closed, swollen-elongate, brown and finely hairy. During expansion, the ascomata split into 3-6 rays that are reminiscent of earth star fungi. The hymenophore color is pale yellow to tan. The ascospores are large, measuring 60-70 x 12-13 $\mu \mathrm{m}$, and are curved-fusoid in shape. All previous records from the United States have been reported from Texas, and the fungus is also known from Japan. The holotype was collected in Austin, Texas in 1891 and described by Charles H. Peck in the genus Urnula.
\end{abstract}

\section{INTRODUCTION}

The second author made a collection of Chorioactis geaster (Peck) Kupfer ex Eckblad (devil's cigar mushroom) in January 2017 in southeast Oklahoma. The fungus belongs to the Ascomycota, Pezizomycetes, Pezizales, Chorioactidaceae. The Pezizales includes the larger ascomycete fungi commonly referred to as cup fungi. This is the first record of the fungus for Oklahoma. In this paper we present a description of the fungus and discuss the current state of knowledge regarding the species' distribution.

\section{MATERIALS AND METHODS}

The collection was made on January 16, 2017, by the second author in Choctaw County, Oklahoma. The material was photographed in situ, dried and sent to the first author who confirmed its identity. The collection is housed in the University of Central Oklahoma Herbarium (CSU). The macroscopic description was compiled from the Oklahoma collections and from previously published descriptions. The microscopic details of the fungus were made by reviving dried sections of the ascomata in $3 \% \mathrm{KOH}$.

\section{DESCRIPTION}

Young ascomata closed, fusoid, club- or cigar-shaped, upper portion hollow, surface densely hairy and brown, dehiscing at stipe apex into 4-7 rays with the resultant apothecia forming a star-shaped pattern reminiscent of earthstars, up to $12 \mathrm{~cm}$ across (Figures 1 and 2). Hymenial surface pale yellow to tan. Stipe cylindrical, up to $7 \mathrm{~cm}$ long, solid, usually buried. Ascospores large, 56-70 x 12-14 $\mu \mathrm{m}$, curved-fusoid, hyaline. Asci $650-750 \times 15-20 \mu \mathrm{m}$, 
8-spored, thick-walled. Paraphyses moniliform, apex narrow and to $3 \mu \mathrm{m}$ wide, hyaline. Surface hairs to 5-10 $\mu \mathrm{m}$ wide, brown, finely spiny or warty.
Oklahoma collection: Choctaw County: Fort Towson, $1 / 2 \mathrm{mi} \mathrm{S}$ of U.S. Hwy $70,1 / 2 \mathrm{mi}$ E of St Hwy 109, 16 Jan 2017, collected by Sheila Brandon. Scattered, in grassy/weedy area, with leaf litter and woody debris.

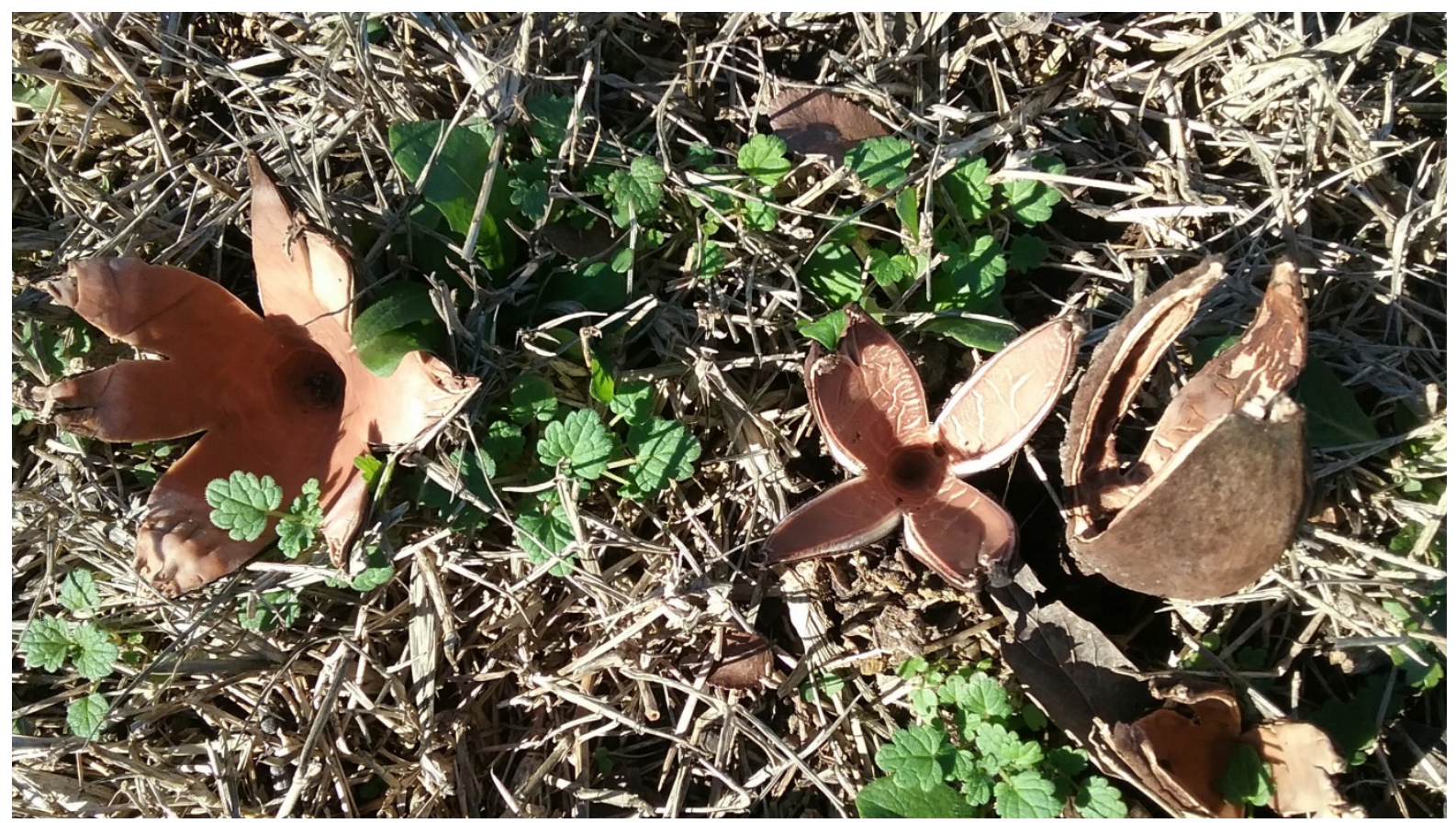

Figure 1 Ascomata in situ

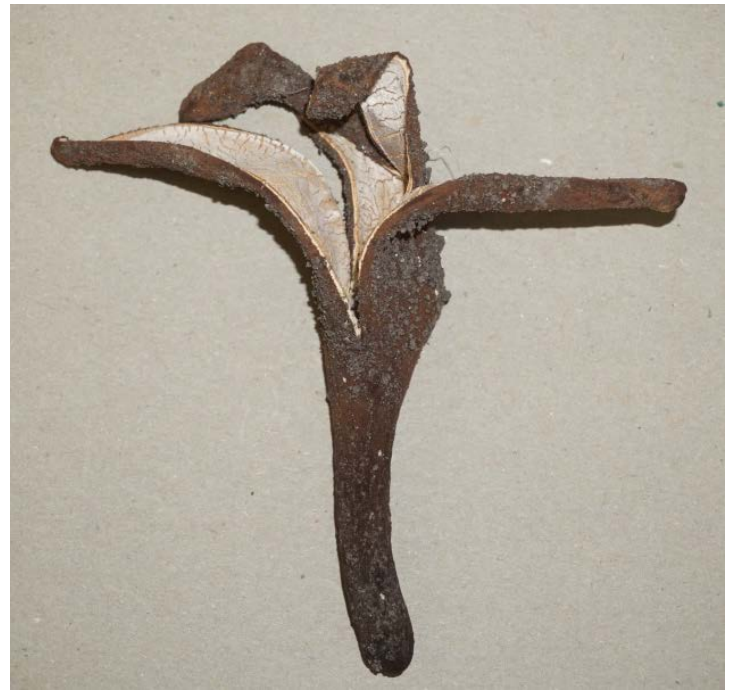

Figure 2 Dried ascoma showing stipe

\section{DISCUSSION}

Choriactis geaster was first described by Charles Horton Peck (1893) in the genus Urnula from material collected in Austin, Texas. Later, the genus Chorioactis was established to accommodate the species (Kupfer 1902; Ekblad 1968). Interestingly, the species was reported from Japan (Miyazaki Prefecture) from a collection made in 1937 (Imazeki 1938) and was rediscovered in Japan at the same location nearly four decades later (Imazeki and Otani 1975). Peterson et al. (2004) undertook a molecular study of the species, analyzing collections from Japan and Texas, and found that collections from the two geographic locations represent two lineages but could not be distinguished morphologically. 
In the United States, the fungus has been known only from central and northcentral Texas with fruiting times being documented from September to March (Rudy 2001; Peterson et al. 2004; Ubelaker and Starks 2005; Watson 2010). Here we report the fungus from Oklahoma for the first time. The Oklahoma fungus was collected in a grassy-weedy-rocky area with decomposed leaf litter. Previously, the area had been covered with honey locust (Gleditsia triacanthos L.), eastern redcedar (Juniperus virginiana L.) and bois d' arc (Maclura pomifera (Raf.) C.K. Schneid.). The species has previously been recorded as being associated with cedar elm (Ulmus crassifolia Nutt.) and often near and attached to stumps or to buried wood (Rudy \& Keller 1996; Rudy 2001). Other reports indicated that the fungus occurred in an open pasture with no stumps or shrubs nearby (Ubelaker and Starks 2005), but it is unclear whether the fungus may have been attached to buried wood. The fungus appears to be a saprotroph, and future collecting will require careful digging to confirm if the ascomata are attached to wood.

Chorioactis geaster was thought to be rare and restricted to Texas, but because of its occurrence in north-central Texas, it is not all that unusual for it to be found in Oklahoma. Future records will likely reveal it to be more broadly distributed at least in the south-central part of the United States.

\section{ACKNOWLEDGMENT}

We thank Ben Liles for providing the collection that was used to make the photograph of the dried ascoma.

\section{LITERATURE CITED}

Eckblad, F.E. 1968. The genera of the operculate Discomycetes: A reevaluation of their taxonomy, phylogeny and nomenclature. Nytt Magasin for Botanik 15:1-191.

Imazeki, R. 1938. A rare fungus. Urnula geaster Peck grows in Kyusyu, Japan. Journal of Japanese Botany 14:680-684.

Imazeki, R and Y. Otani. 1975. Rediscovery of Chorioactis geaster (Peck) Eckblad in Kyusyu, Japan. Transactions of the Mycological Society of Japan 16:222-229.

Kupfer, E.M. 1902. Studies on Urnula and Geopyxis. Bulletin of the Torrey Botanical Club 29(3):137-44.

Peck, C.H. 1893. Forty-sixth report of the State Museum. Annual Report of the State Botanist of the State of New York 49:39.

Peterson K.R, C.D. Bell, S. Kurogi, and D.H. Pfister. 2004. Phylogeny and biogeography of Chorioactis geaster (Pezizales, Ascomycota) inferred from nuclear ribosomal DNA sequences. Harvard Papers in Botany 8(2):141-152.

Rudy, K.C. 2001. The devil's cigar - the hunt continues. Mycophile 42(6):1, 4-5.

Rudy, K. and H.K. Keller. 1996. The rare and fascinating devil's cigar, Chorioactis geaster. Mycologist 10(1):33-35.

Ubelaker J.E.and J.K. Starks. 2005. A new record of the devil's cigar, Chorioactis geaster (Pezizales: Ascomycota), from Collin County, Texas. Sida 21(3):1939_ 1940.

Watson, T. 2010. Rare mushroom found at Onion Creek. Hays County Master Naturalist Newsletter, February 2010. Online pdf: http://haysmn.org/downloads/HCMN NewsFeb10.pdf 